\title{
Past and Future Drivers of an Unmanaged Carbon Sink in European Temperate Forest
}

\author{
Katherine A. Allen, ${ }^{1 *}$ Veiko Lehsten,${ }^{2}$ Karen Hale,${ }^{1}$ and Richard Bradshaw ${ }^{1}$ \\ ${ }^{1}$ School of Environmental Sciences, University of Liverpool, Liverpool L69 3GP, UK; ${ }^{2}$ Department of Physical Geography and \\ Ecosystem Science, Lund University, Lund, Sweden
}

\begin{abstract}
Forests are major carbon stores on a global scale but there are significant uncertainties about changes in carbon flux through time and the relative contributions of drivers such as land use, climate and atmospheric $\mathrm{CO}_{2}$. We used the dynamic vegetation model LPJ-GUESS to test the relative influence of $\mathrm{CO}_{2}$ increase, temperature increase and management on carbon storage in living biomass in an unmanaged European temperate deciduous forest. The model agreed well with living biomass reconstructed from forest surveys and maximum biomass values from other studies. High-resolution climate data from both historical records and general circulation models were used to force the model and was manipulated for some simulations to allow relative contributions of individual drivers to be assessed. Release from management was the major driver of carbon storage for most of the historical period, whereas $\mathrm{CO}_{2}$ took over as the most
\end{abstract}

important driver in the last 20 years. Relatively, little of the observed historical increase in carbon stocks was attributable to increased temperature. Future simulations using IPCC RCP4.5 and RCP8.5 scenarios indicated that carbon stocks could increase by as much as $3 \mathrm{~kg} \mathrm{C} \mathrm{m}^{-2}$ by the end of the century, which is likely to be driven by $\mathrm{CO}_{2}$ increase. This study suggests that unmanaged seminatural woodland in Europe can be a major potential carbon sink that has been previously underestimated. Increasing the area of unmanaged forest would provide carbon sink services during recovery from timber extraction, while long-term protection would ensure carbon stocks are maintained.

Key words: forest management; carbon storage dynamics; dynamic vegetation model; LPJ-GUESS; climate change; atmospheric $\mathrm{CO}_{2}$.
Received 28 May 2015; accepted 23 October 2015 . published online 14 January 2016

Electronic supplementary material: The online version of this article (doi:10.1007/s10021-015-9950-1) contains supplementary material, which is available to authorized users.

Author contributions All authors contributed to the conception and design of the study and writing of the paper. Katherine Allen performed the modelling work and data analysis. Karen Hale and Richard Bradshaw collected and analysed the field data. Veiko Lehsten contributed new methods and modelling design.

*Corresponding author; e-mail: kaallen@liverpool.ac.uk

\section{INTRODUCTION}

Global forests provide a substantial and important carbon store but significant uncertainties exist about the drivers of changes in carbon flux through time (Erb and others 2013; Mackey and others 2013). Over the last 300 years, the US forests have switched from being a carbon source to a carbon sink (Birdsey and others 2006) and this is also likely to have occurred in China and Europe because of reforestation and reduction of intensive 
land-use practices, which are returning carbon to forest ecosystems (Erb and others 2013; Mackey and others 2013). Indeed Mackey and others (2013) estimate that global terrestrial ecosystems currently act as a significant net carbon sink, due to recovery from past land use (especially deforestation and logging). Estimates for recent changes in carbon fluxes are available at global (Pan and others 2011) and regional (Birdsey and others 2006; Ciais and others 2008) scales, but uncertainty remains about the drivers of these changes, which may include reduced management, $\mathrm{CO}_{2}$ fertilization, nitrogen availability and climatic influence on photosynthesis and respiration. Bellassen and others (2011) used a dynamic vegetation model to suggest that $\mathrm{CO}_{2}$ fertilization and climate change were the dominant influences on carbon stocks in European forests between AD 1950 and 2000, whereas Erb and others (2013) stressed the role of management relaxation. The relationship between these drivers of carbon flux in terrestrial ecosystems is likely to have shifted through the recent past and will continue to do so in future.

Increases in forest carbon stocks in the recent past are commonly reported and have been estimated at $1.7 \mathrm{~kg} \mathrm{C} \mathrm{m}^{-2}$ in the last 50 years in Europe (Ciais and others 2008) and $0.5 \mathrm{~kg} \mathrm{C} \mathrm{m}^{-2}$ in the last 17 years in the United States (Pan and others 2011). This is most commonly attributed to increased forest density due to recovery from more intense management (Rautiainen and others 2011; Erb and others 2013), or changes in atmospheric composition or climate (for example, Bellassen and others 2011; Mackey and others 2013). A metaanalysis of free-air $\mathrm{CO}_{2}$ enrichment (FACE) experiments revealed that elevated $\mathrm{CO}_{2}$ resulted in larger plants, with greater allocation to wood and increased biomass production in trees (Ainsworth and Long 2005). The effect of climate warming is less clear, as carbon stocks may be increased in some regions through extended growing seasons due to increased temperature, but may also be reduced by negative effects on plant growth through drying or heat stress (Mackey and others 2013).

The capacity to store carbon in vegetation is ultimately limited, although the maximum will change with prevailing environmental conditions. Carbon carrying capacity at a landscape scale has been defined as the mass of carbon stored in an ecosystem under prevailing environmental conditions and natural disturbance regimes, but excluding anthropogenic disturbance (Keith and others 2010). Ciais and others (2008) suggested a potential maximum carbon stock of $17 \mathrm{~kg} \mathrm{C} \mathrm{m}^{-2}$ for broad-leaved forests $\left(14-15 \mathrm{~kg} \mathrm{C} \mathrm{m}^{-2}\right.$ for for- ests in general) using managed forest data, although such inventory data may underestimate the true carbon carrying capacity significantly (Keith and others 2009). A review of global and European datasets revealed that most forests are below or close to this suggested maximum, but some forests already store considerably more (for example, Mountford and Peterken 2003). These may be primary forests which are under-represented in the data used by Ciais and others (2008), but it is possible that as a forest recovers from management, it may exceed its theoretical maximum until selfthinning processes restore equilibrium densities (Shugart 1998). Therefore, as much primary European forest is recovering from some form of timber extraction, these elevated levels may still subside to a long-term maximum.

Native temperate deciduous forests account for $36.7 \%$ of European forest cover and $12.8 \%$ $\left(1.2 \times 10^{8} \mathrm{ha}\right)$ of European land area (Schuck and others 2002). Most of this forest is managed or experiencing the effects of management legacy (for example, Erb and others 2013) and only $26 \%$ of Europe's forest is now primary forest (FAO 2010). Unmanaged forest has the potential to store more carbon as living biomass than forest experiencing current or recent timber extraction, although it is not clear by how much. Keith and others (2009) reported biomass data from mature and older forests to be 2-3 times the temperate biome default values (from forest inventory data) used to inform climate change mitigation policies (IPCC 2013). Better understanding of the role of management in determining carbon flux in forests, and how it relates to other drivers such as atmospheric $\mathrm{CO}_{2}$ fertilization and climatic change is clearly crucial for guiding policy to optimize carbon storage.

Here, we use long-term monitoring data from a European, temperate, semi-natural, deciduous forest to reconstruct carbon storage in living biomass. This forest has been unmanaged since 1945 and as such represents an important contrast to studies of plantations and managed forests. We compared output from the dynamic vegetation model LPJ-GUESS with long-term monitoring data to establish reliability of simulated carbon stock estimates. We then used the model to explore the sensitivity of forest carbon stocks in this region to temperature, precipitation, $\mathrm{CO}_{2}$ and management. Simulation results were compared to estimate the relative contribution of different variables to carbon fluxes during the last 65 years. Only living biomass (above- and below-ground) was considered; carbon stored in soils and dead biomass was omitted. The nitrogen cycle is not represented in 
LPJ-GUESS, and therefore, $\mathrm{N}$ fertilization could not be considered.

\section{Materials AND Methods}

\section{Site Description and Data Collection}

Lady Park Wood is an ancient, semi-natural woodland in the UK $\left(51^{\circ} 49^{\prime} \mathrm{N}, 2^{\circ} 39^{\prime} \mathrm{W} ; 30-190 \mathrm{~m}\right.$ elevation), which was coppiced for centuries but designated an unmanaged nature reserve in 1945. The main species present are beech (Fagus sylvatica L.), oak (Quercus petraea (Matt.) Liebl.), ash (Fraxinus excelsior L.), lime (Tilia cordata Mill., T. platyphyllos Scop.), wych elm (Ulmus glabra Huds.) and birch (Betula pendula Roth). The reserve covers 35.2 ha, of which 14 ha (old-growth stands) have experienced no management since about 1900 when approximately $50 \%$ of tree biomass was removed (Peterken and Jones 1987). We follow Peterken and Jones $(1987,1989)$ in the use of the term "old-growth" for describing mature stands within the wood. These stands are dominated by trees of ages that many authors have judged to be in the old-growth age for temperate broad-leaved deciduous forest, although providing a concise scientific definition of the term "old-growth" has been judged to be an impractical task (Wirth and others 2009). The oldest trees in Lady Park Wood are about 220 years and these stands have been well stocked with standing dead trees since 1976 when many were killed by drought (Cavin and others 2013). Canopy height and basal area have oscillated around a ceiling achieved by 1976 and the volume of coarse woody debris in the 1990's was similar to temperate deciduous 'virgin' forests and USA old-growth forests. The remaining 21 ha (young-growth stands) were virtually clear-felled in 1943 (Peterken and Jones 1989).

Estimates of carbon storage in living biomass from Lady Park Wood were used to ground truth LPJ-GUESS estimates. Transects were established in old and young-growth areas in 1944. Old-growth transects were recorded in 1945, 1955, 1977, 1983, 1986, 1992, 2000 and 2010 and young-growth transects in 1977, 1993 and 2002 (details in Peterken and Jones 1987, 1989). These long-term monitoring data (Mountford, E. unpub) provide location, species and diameter of all trees achieving at least $1.3 \mathrm{~m}$ height. Allometric regression equations were used to calculate living biomass in order to reconstruct long-term carbon dynamics. Speciesspecific equations were used where available and otherwise the equation for a similar species was substituted. Carbon content was assumed to have a mean of $48.8 \%$ (Thomas and Martin 2012). For more detail see supplementary material.

\section{The LPJ-GUESS Model}

LPJ-GUESS (Smith and others 2001) is a dynamic vegetation model that uses a gap modelling approach (Shugart 1984; Prentice and others 1993; Bugmann 2001). Various plant functional types (representing groups of species with similar functional traits) and species can be simulated (hereafter PFT refers to both PFTs and species) (Hickler and others 2004). Bioclimatic limits (Prentice and others 1992; Sykes and others 1996) are used to define the climate space in which each PFT may occur. Biophysical and physiological processes are represented mechanistically, using the formulations given in Sitch and others (2003) for LPJDGVM, which uses an area-averaged representation of vegetation structure. In contrast, LPJGUESS simulates vegetation as age cohorts of different species, competing for light and water on replicate patches (100 in the present study). The model is driven by short-wave radiation (photosynthetically active light), temperature, precipitation and $\mathrm{CO}_{2}$ concentration of the air. Soil conditions modify the water uptake of the plant. $\mathrm{CO}_{2}$ influences assimilation rate following the Farquhar and others (1980) approach.

Twenty-two PFTs and species were modelled including the major tree and shrub species plus a group comprising grasses and herbaceous plants, which compete with trees for resources. We used the full set of PFTs to test the capability of LPJGUESS to reproduce the current stage of the vegetation. Bioclimatic limits determine whether plants establish and whether they die in cold spells (for details and species-specific parameters see Hickler and others 2012). Each PFT also has a specific drought tolerance, characterised by its water uptake rate. Summergreen species require varying periods of chilling to induce budburst (Murray and others 1989). Cohort establishment and mortality are modelled as stochastic processes within each patch. In addition, stochastic patchdestroying disturbances, representing processes such as herbivory and storm damage, result in all vegetation in a patch being transferred to the patch's litter pool and occur with an annual probability of $1 / 500$.

\section{Model Forcing and Simulation Protocol}

To equilibrate initial vegetation and carbon pools with climate at the beginning of the study period, the model was first "spun-up" for 1000 years using 
climate data for the period 1901-1930 cycled repeatedly and the $1901 \mathrm{CO}_{2}$ value. The study period then ran from 1901 to 2005 . Temperature, precipitation and short-wave radiation data for 1901-2005 were taken from the WATCH dataset (Weedon and others 2011). Both WFD (19011978) and WFDEI (1979-2005) were used to cover the study period and a bias correction was applied to the WFD data to create a continuous dataset. Locally measured daily temperature and precipitation data were also available from Ross on Wye (11 km from site) for years 1961-2005 (UK Meterological Office). These data were used in place of the WATCH dataset for the available years and the WATCH dataset was further bias corrected using these local data (see supplementary material for method). Missing values in the local station climate data were interpolated using a linear relationship $\left(r^{2}=0.94, P<0.0001\right)$ with data from Preston Wynne (34 km from site). Atmospheric $\mathrm{CO}_{2}$ was taken from the RCP Concentration Calculation and Data Group (Meinshausen and others 2011). Simulations using modifications of these data are described below.

To project future carbon pools, temperature, precipitation and short-wave radiation for the period 2006-2100 were calculated to represent the IPCC representative concentration pathways (RCP) 4.5 and 8.5, which project an approximate $40 \%$ increase in atmospheric $\mathrm{CO}_{2}$ from 2006 to 2100 or a $250 \%$ increase, respectively. These scenarios were chosen as they represent the two extremes of global temperature increase by 2100 , within the range given by the IPCC AR5 report (IPCC 2013) for both stabilization scenarios (RCP4.5 and RCP6.0) and high greenhouse gas emission scenarios (RCP8.5). The RCP2.5 is considered highly unlikely and the derived climate data are not yet available. The two chosen scenarios are to some extent comparable to the AR4 SRES scenarios Bl and A2. Climate projections for the period were taken from CORDEX (Coordinated Regional Climate Downscaling; http://www.euro-cordex.net/) using data downscaled to high resolution ( $11^{\prime}$ longitude/latitude). We used downscaled climate data for the grid cell containing Lady Park Wood from the CMIP5 ensemble general circulation models (GCMs) HadGEM, MPI, IPSL and CNRM. These were the only models for which downscaled data at high resolution for RCPs 4.5 and 8.5 were available. Anomalies for each month in each future year were calculated as the difference between the future month mean and the climatology (monthly mean across all years 1970-2005) for each climate variable. Daily data for the relevant climate vari- able from the period 1970-2005 were cycled through repeatedly to provide a baseline for future climate, maintaining intra-annual variation, and anomalies were applied to these data. A significant increasing trend was identified in the station temperature data, however, and this trend was removed before applying anomalies. For further details see supplementary material.

\section{Comparison of Monitoring Data with Model Output}

Vegetation dynamics in Lady Park Wood were simulated in LPJ-GUESS for the period 19012005; firstly without simulated clearance, to represent the carbon carrying capacity of the forest in a "natural" state with no history of anthropogenic disturbance or management. This hypothetical simulation provides a baseline against which carbon stocks under other real or modelled conditions can be compared and is referred to as "noclearance" throughout. The clear-felling (100\% biomass removal) that took place in the younggrowth areas of Lady Park wood in 1943 and the partial felling $(50 \%)$ of old-growth stands in 1901 were then simulated. These results were compared with observed old- and young-growth biomass data.

\section{Relative Effects of Temperature, $\mathrm{CO}_{2}$ and Management}

Using the old-growth simulation as a baseline, simulations with no-clearance, with de-trended temperature throughout and de-trended $\mathrm{CO}_{2}$ throughout were then compared. This allowed consideration of how different carbon storage would have been if each observed effect had not been present. As no trend in precipitation or radiation was identified in the weather data, the effects of these variables could not be examined, but they cannot have been drivers of the observed biomass increase.

\section{Extreme Weather}

Different climate variables are related strongly to each other; for example, years with higher than average summer temperatures are likely to have decreased precipitation. Hence, when investigating the effect of temperature, changing temperature alone in the driving data would be an oversimplification (but see supplementary material). The extreme climate experiments assessed the effect of climate factors by replicating years in which those factors were unusually pronounced (for example, dry years). Local weather data were ranked in terms of temperature or precipitation levels and the 
Table 1. Summary of Weather Conditions During Top Ranking Years for Mean Temperature (March to September) and Precipitation (May to July)

\begin{tabular}{llll}
\hline Top 5 & Mean temp Mar-Sep $\left({ }^{\circ} \mathrm{C}\right)$ & Mean prec May-Jul $(\mathrm{mm})$ & Years \\
\hline Warmest & 13.70 & 1.07 & $1989,1990,1995,1997,1999$ \\
Driest & 12.98 & 0.89 & $1975,1976,1978,1984,1995$ \\
Coldest & 11.57 & 1.83 & $1962,1965,1972,1974,1986$ \\
Wettest & 12.18 & 2.60 & $1967,1968,1969,1985,1993$
\end{tabular}

Climate data from these years were used to produce Figure 3.

top five warmest, coldest, wettest and driest years were extracted (Table 1) and cycled through repeatedly to simulate an extreme climate. By using real daily data from these top ranking years, the relationship between temperature, precipitation and radiation was preserved. Clearance was not simulated here in order to focus on the effects of climate.

\section{Future Projections}

The potential for carbon storage as biomass towards the end of this century was projected using climate data representing IPCC AR5 scenarios RCP4.5 and RCP8.5. The model was run to 2100 , using the end of the no-clearance and young-growth simulations as starting points, the old-growth simulation was not used as its end point in 2000 was very similar to the no-clearance simulation.

\section{RESUltS}

\section{Comparison to Data}

Carbon stocks increased in old-growth unmanaged stands by $8.5 \mathrm{~kg} \mathrm{~m}^{-2}$ over 65 years and in younggrowth stands by $9 \mathrm{~kg} \mathrm{~m}^{-2}$ over 57 years [Figure 1; see Hale (2015) for more details]. Simulations of the partial clearance in 1901 and clear-felling in 1943 agree relatively well with these data (mean difference in years with data points $=-0.61$ and $0.29 \mathrm{~kg} \mathrm{~m}^{-2}$, respectively), with modelled values falling within the limits of the $95 \%$ confidence intervals of observed values in all cases except the two earliest old-growth observations (mean difference $-2.23 \mathrm{~kg} \mathrm{~m}^{-2}$ ). By the year 2005, simulated carbon mass in old-growth stands approaches the values of the no-clearance simulation, suggesting recovery from timber extraction is almost complete, in terms of biomass. The model correctly identified the major tree species (Fagus, Quercus, Fraxinus, Tilia,

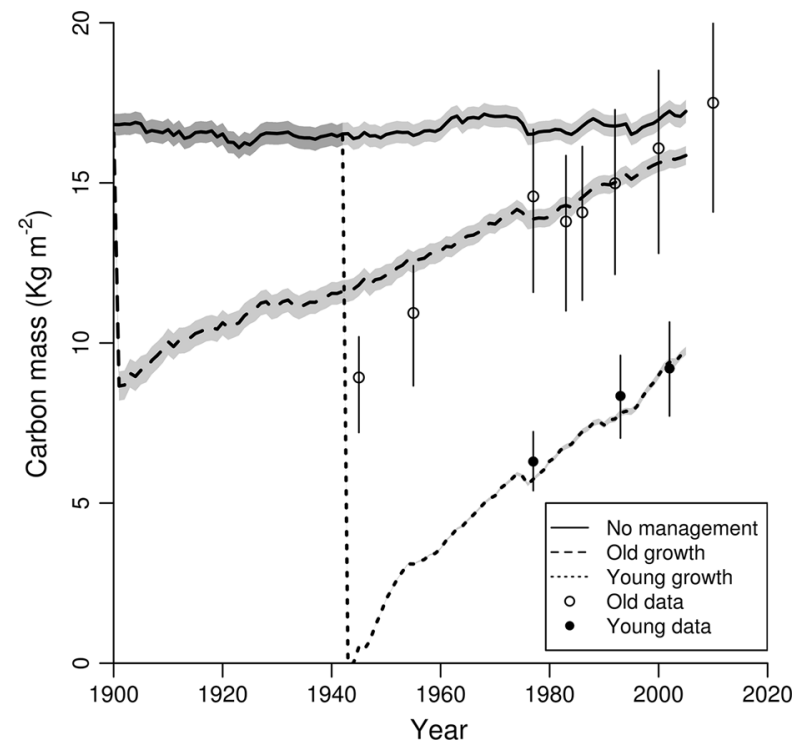

Figure 1. Observed biomass in old- (open circles) and young-growth stands (filled circles) at Lady Park Wood and LPJ-GUESS output representing carbon mass under various past management conditions (lines represent mean values): 50\% clearance of all tree species in 1901 representing the old-growth stands (dashed); total clearance in 1943 representing young-growth stands (dotted); and no-clearance representing the potential carbon carrying capacity or 'natural' state with a mosaic of age cohorts and no anthropogenic disturbance (solid). Shaded regions represent the standard error of mean values. Error bars on data points are bootstrapped $95 \%$ confidence intervals.

Ulmus and Betula) but tended to overestimate Quercus abundance and underestimate Fraxinus and Tilia. This may indicate that some model parameterisations were sub-optimal for local conditions, although models can never perfectly recreate observed conditions due the random effects on vegetation establishment in multi species mixtures. 


\section{Relative Effects of Temperature, $\mathrm{CO}_{2}$ and Management}

The no-clearance simulation represents the carbon carrying capacity of Lady Park Wood if no management had ever been applied. Simulated carbon storage was more than $50 \%$ greater in the noclearance than in the old-growth simulation in 1900, although the difference decreased through time as old-growth stands recovered. The size of this difference reveals that, for most of the study period, management legacy is the most important factor determining carbon stored in living biomass (Figure 2), and has a large but decreasing negative effect on carbon mass as the forest recovers from

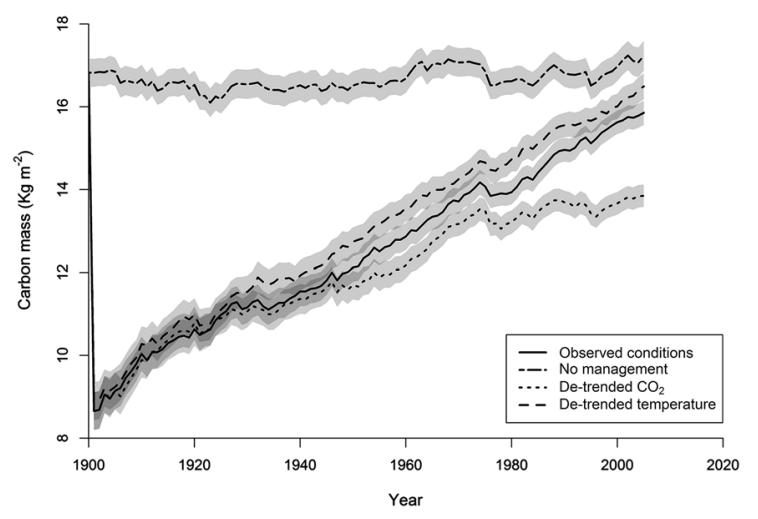

Figure 2. LPJ-GUESS output showing the effect on stored carbon of removing single variables relative to observed conditions in old-growth stands (that is, 50\% tree clearance in 1901, increasing temperature and $\mathrm{CO}_{2}$; solid line). The effect of management was removed by running the model without simulated clearance (long dashes). $\mathrm{CO}_{2}$ was de-trended by using 1901 levels throughout (dotted line). Temperature was de-trended using a linear regression (short dashes; see text). Lines represent means of 500 replicate patches and shaded areas represent standard error. past felling. Conversely, $\mathrm{CO}_{2}$ has an increasingly large positive effect as atmospheric levels rise, indicated by reduced carbon mass when $\mathrm{CO}_{2}$ is detrended. Indeed, by the end of the period, the positive effect of $\mathrm{CO}_{2}$ is larger than the negative effect of management legacy (Table 2). Temperature has a much smaller effect, which is negative overall. This suggests that the increase in forest biomass observed over the last century is more attributable to $\mathrm{CO}_{2}$ fertilization than to warmer conditions in Lady Park Wood.

\section{Effects of Extreme Climate Conditions}

Figure 3 compares the extreme climate simulations to that without climate manipulation (all without clearance). Under dry conditions carbon stored as living biomass was reduced (mean difference $-5.84 \pm 0.31 \mathrm{~kg} \mathrm{C} \mathrm{m}^{-2}$ across years 1900-2000), whereas under wet conditions biomass production did a little better than under actual climate $\left(1.30 \pm 0.33 \mathrm{~kg} \mathrm{C} \mathrm{m}^{-2}\right)$. However, biomass production was also greatly suppressed under warm conditions $\left(-2.62 \pm 0.36 \mathrm{~kg} \mathrm{C} \mathrm{m}^{-2}\right)$ and increased in cold conditions $\left(0.97 \pm 0.45 \mathrm{~kg} \mathrm{C} \mathrm{m}^{-2}\right)$.

\section{Future Carbon Storage}

During the period 2006-2100, carbon stored as living biomass was projected to either maintain approximately 2005 levels or increase by up to $3 \mathrm{~kg} \mathrm{C} \mathrm{m}^{-2}$ in the simulations with no historical clearance. In the young-growth stands, carbon storage increased rapidly to approach simulated levels without historical clearance $\left(17 \mathrm{~kg} \mathrm{C} \mathrm{m}^{-2}\right.$ in 2000) and, in some cases, continued to rise by up to $4 \mathrm{~kg} \mathrm{C} \mathrm{m}^{-2}$ (Figure 4). There are some consistent differences between GCMs but the overall trends are very similar in most cases. Regardless of clearance history or GCM, the difference between the two RCPs is small.

Table 2. Projected Carbon Mass Values in 1960, 1980 and 2000 (Mean \pm SD)

\begin{tabular}{lcccccc}
\hline Simulation & 1960 Cmass & $\Delta$ Cmass & 1980 Cmass & $\Delta$ Cmass & 2000 Cmass & $\Delta$ Cmass \\
\hline Observed temperature \& $\mathrm{CO}_{2}$ with & $12.87 \pm 7.18$ & 0.00 & $13.93 \pm 6.48$ & 0.00 & $15.63 \pm 6.36$ & 0.00 \\
$\quad 50 \%$ clearance in 1901 & & & & & & \\
De-trended $\mathrm{CO}_{2}$ & $12.17 \pm 7.00$ & -0.7 & $13.21 \pm 6.31$ & -0.72 & $13.67 \pm 6.10$ & $\mathbf{- 1 . 9 6}$ \\
De-trended temperature & $13.56 \pm 7.30$ & 0.69 & $14.73 \pm 6.62$ & 0.8 & $16.01 \pm 6.78$ & 0.33 \\
No-clearance & $16.68 \pm 7.64$ & $\mathbf{3 . 8 1}$ & $16.62 \pm 7.27$ & $\mathbf{2 . 6 9}$ & $16.97 \pm 7.74$ & 1.34 \\
\end{tabular}

The simulation using observed conditions represents old-growth conditions as a baseline. $\Delta$ Cmass shows the difference between each modified condition and that baseline. The biggest driver of $C$ mass at each time point is highlighted in bold text. 

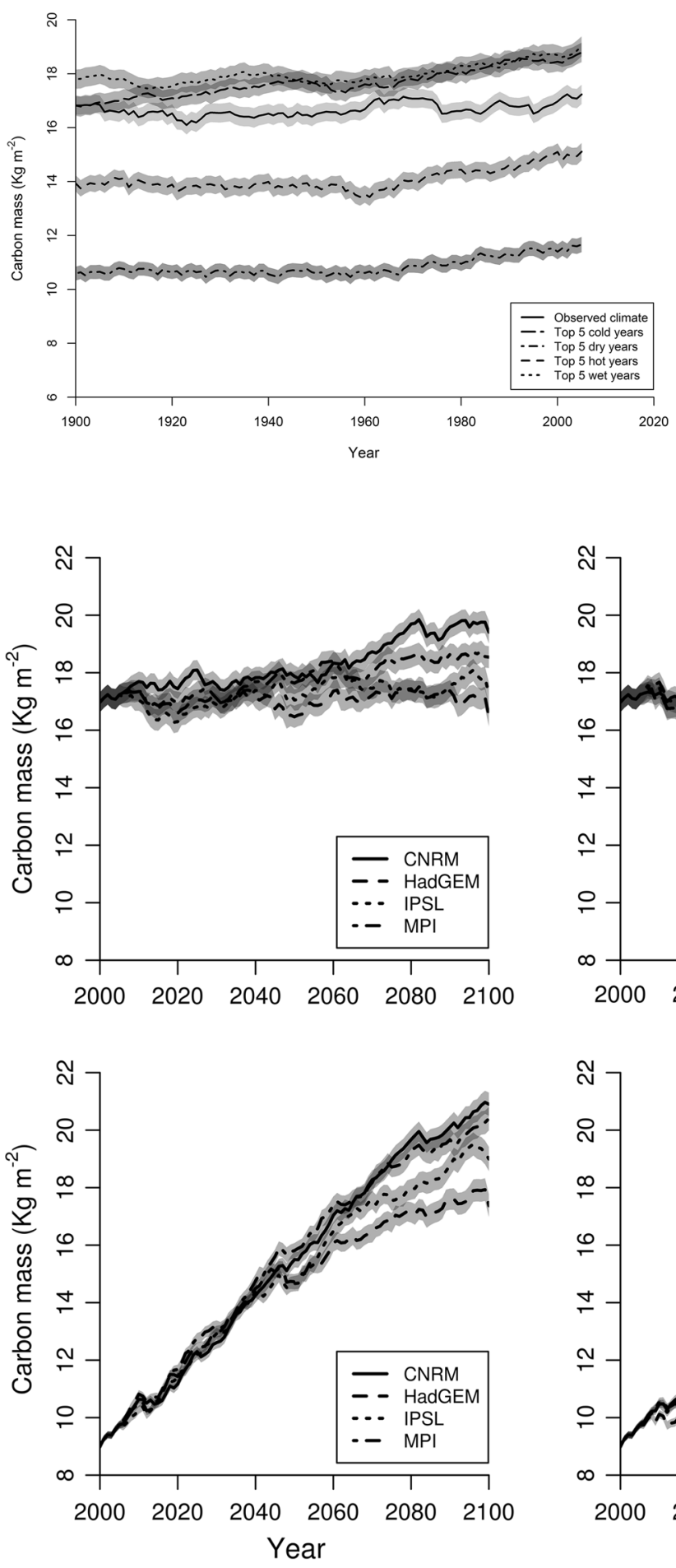

\section{Discussion}

Monitoring data reveal that, since release from management, the old-growth stands in Lady Park Wood have more than doubled their carbon storage as living biomass (Figure 1). Furthermore, greater biomass appears to be possible and still rising (oldgrowth stands in $2010=18.11 \mathrm{~kg} \mathrm{C} \mathrm{m}^{-2}$ ). This al-
Figure 3. Effects of extreme weather conditions on stored carbon simulated by LPJGUESS using local weather data from the most extreme 5 years in terms of high /low temperature and high/ low rainfall. Lines represent means of 500 replicate patches and shaded areas represent standard error.

Figure 4. Future projections of carbon mass in Lady Park Wood using the RCP4.5 (left) and RCP 8.5 (right) climate models. The starting point for future projections was the noclearance simulation (top) and new growth simulation (bottom). Lines represent means of 500 replicate patches and shaded areas represent standard error.

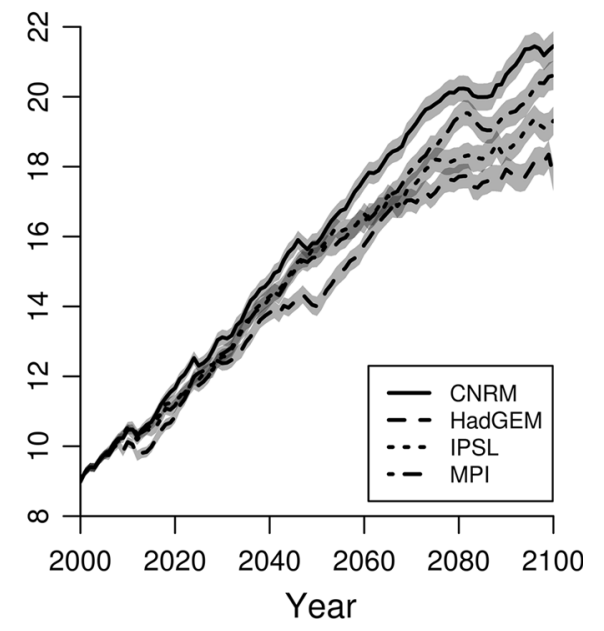

ready exceeds the $17 \mathrm{~kg} \mathrm{C} \mathrm{m}^{-2}$ maximum potential biomass suggested by Ciais and others (2008) for European broad-leaved forest, although it may be within the range of natural variability. Previous estimates of current carbon sequestration have been based mostly on inventories of commercial forests in the European temperate zone and are 
lower than the values we report from this unmanaged area, which may still be at the lower end of the UK range. In the New Forest $\left(50^{\circ} 51.5^{\prime} \mathrm{N}\right.$ and $1^{\circ} 32.5^{\prime} \mathrm{W}$ ), for example, a value of $28 \mathrm{~kg} \mathrm{C} \mathrm{m}^{-2}$ has been recorded (Hale 2015). The potential range of carbon in above-ground living biomass for American, Chinese and Australasian temperate forest given by Keith and others (2009) (c. 15$38 \mathrm{~kg} \mathrm{C} \mathrm{m}^{-2}$ ) therefore also seems accurate for European forest, even under sub-optimal conditions. The no-clearance simulations represent the potential carbon carrying capacity as living biomass in Lady Park Wood if no management had ever been applied. At around $17 \mathrm{~kg} \mathrm{C} \mathrm{m}^{-2}$, it is similar to the suggested max of $17 \mathrm{~kg} \mathrm{C} \mathrm{m}^{-2}$ for broadleaved forest (Ciais and others 2008). Future projections in the no-clearance stands showed either stability at 2005 levels or an increase towards the end of the century of up to $3 \mathrm{~kg} \mathrm{C} \mathrm{m}^{-2}$ (Figure 4). However, the time scale is relatively short for forest dynamics and longer projections would be required to determine where carbon levels might stabilize in the long-term.

Management had the greatest effect on carbon stocks throughout most of the study period (Table 2; Figure 2). However, towards the end of the study period, $\mathrm{CO}_{2}$ has taken over as the bigger driver. This has a parallel with Erb and others' (2013) work in Austria, where a shift from management to 'climate and management' was identified as the major driver of mean annual increment during the latter part of the twentieth century, although they did not distinguish $\mathrm{CO}_{2}$ from climate. Relatively little of the observed historical increase in carbon stocks was attributable to climatic change, once the effects of increasing $\mathrm{CO}_{2}$ and management were removed.

Climate manipulation experiments demonstrated that increased temperature (and associated rainfall reduction) had negative effects on carbon storage even though warmer conditions have been proposed to stimulate net primary productivity at northern latitudes (for example, Zaehle and others 2007) and this can also be demonstrated by manipulating temperature or precipitation in isolation (see supplementary material). Although less precipitation will clearly cause water limitation, increased temperatures can also cause water stress by increasing demand for water. Furthermore, assimilation is inhibited in LPJ-GUESS by a negative effect of temperature on light-use efficiency above $5^{\circ} \mathrm{C}$, which has been demonstrated experimentally (Farquhar and others 1980; Haxeltine and Prentice 1996). A negative effect of increased temperature might be rather unusual in a Euro- pean context, since most temperate broad-leaved forests occur in areas with a continental climate, and therefore more pronounced temperature seasonality and longer winters. Under these conditions, an increase in temperature would extend the growing season, allowing more photosynthesis and therefore productivity. However, at Lady Park Wood the climate is oceanic, therefore the growing season could be only marginally extended as temperatures are generally above the photosynthesis threshold already. Any positive effect on winter net primary productivity would be outweighed by a decrease over summer, when increased temperature would increase water demand and reduce light-use efficiency. At other locations with a more continental climate a higher annual temperature may result in increased productivity.

Carbon mass in old-growth stands was approaching "natural" levels by 2005, which indicates an approximate 100-year recovery time from $50 \%$ clearance. Recovery from $100 \%$ clearance might be expected to take significantly longer, but Figure 4 shows projected recovery times of 110-140 years. Therefore, intensively managed forest stands may recover relatively quickly if released from management. Any increase in growth rate is likely to be driven by increased $\mathrm{CO}_{2}$ levels rather than associated warming (Figure 2). In the simulations of "natural" forest without historical clearance, forecasts of carbon stocks for the next century based on the two RCPs are qualitatively similar over the first decades. In the latter period, all climate models show some increase under RCP8.5, of between 1 and $3 \mathrm{~kg} \mathrm{C} \mathrm{m}^{-2}$, whereas for RCP4.5 some show a comparable increase, whereas others project a continuing stable state around $17 \mathrm{~kg} \mathrm{C} \mathrm{m}^{-2}$.

LPJ-GUESS has been used in a large number of studies and its performance has been evaluated several times. Lehsten and others (2015, Appendix S4) reviewed evaluations of model performance and uncertainty of parameters. Numerous applications have added a feature to LPJ-GUESS in cases where the standard model was not sufficient to describe a certain phenomenon, for example LPJGUESS has been coupled to a climate model to look at feedbacks of vegetation on climate change (Wramneby and others 2010). Current developments include the incorporation of the $\mathrm{N}$ cycle and a representation of peatland processes, although these were not available for this study.

This study was confined to living biomass carbon stocks, which are closely related to soil and dead biomass carbon stocks. Currently in Lady Park Wood, 29\% of carbon stocks are in the soil and 3\% 
in coarse woody debris within the old-growth stands and $46 \%$ and 5\%, respectively, in the young-growth stands (Hale 2015). These values are rather low compared with other sites in the UK because of the thin soil cover on the steeply sloping site (Vanguelova and others 2013).

Previous European estimates of carbon storage as biomass have been far lower than the values we report from this unmanaged area, where both model and data approach the potential maximum stock estimated from old forest data and yield tables (Ciais and others 2008). However, this potential maximum is likely to be site dependent and is significantly exceeded in other old-growth deciduous forests in the UK (Hale 2015). Native temperate deciduous forests cover a significant amount of European land area $(12.8 \%$ or $1.2 \times 10^{8}$ ha) (Schuck and others 2002) but are mostly managed for some level of timber extraction. Nabuurs and others (2013) reported that European forests are approaching equilibrium with the current level of management and thus the carbon sink effect is declining.

This study suggests that forests released from management can provide a major carbon sink during the recovery phase, as suggested by Erb and others (2013) and Mackey and others (2013). Consequently, the contribution of European native deciduous forests to recent carbon sequestration is likely to be significant when total ecosystem carbon is considered and this contribution has almost certainly been underestimated in the UK for the latest Global Forest Resources Assessment, where observations from plantations predominated (FAO 2010; Hale 2015). However, there are strict environmental limits on the carbon carrying capacity of a degraded forest and further limits on the degree to which that can be restored. The ultimate value of these areas for carbon mitigation therefore lies in their long-term preservation, rather than their current sink status (Mackey and others 2013). Therefore increasing the area of unmanaged seminatural woodland in Europe will help to maximize the positive effect of $\mathrm{CO}_{2}$ fertilization on their carbon sink status and mitigate any negative effect due to associated climate warming. Protecting these areas in the long-term will ensure carbon stocks are maintained and that a return to source behaviour does not occur.

\section{ACKNOWLEDGEMENTS}

We thank NERC for financial support through Grant NE/002096/1 and the Swedish Foundation for International Cooperation in Research and
Higher Education through project DYNAMITE. Veiko Lehsten's research was funded by the ERANet BiodivERsA, with the national funders FORMAS, part of the 2011 BiodivERsA call for research proposals. Rob Marrs and Gregg Milligan made valuable comments on the manuscript. We thanks Matthew Spencer for his contribution to processing the field data.

\section{OPEN ACCESS}

This article is distributed under the terms of the Creative Commons Attribution 4.0 International License (http://creativecommons.org/licenses/by/ 4.0/), which permits unrestricted use, distribution, and reproduction in any medium, provided you give appropriate credit to the original author(s) and the source, provide a link to the Creative Commons license, and indicate if changes were made.

\section{REFERENCES}

Ainsworth EA, Long SP. 2005. What have we learned from 15 years of free-air $\mathrm{CO}_{2}$ enrichment (FACE)? A meta-analytic review of the responses of photosynthesis, canopy properties and plant production to rising $\mathrm{CO}_{2}$. New Phytol 165:351-72.

Bellassen V, Viovy N, Luyssaert S, Le Maire G, Schelhaas MJ, Ciais P. 2011. Reconstruction and attribution of the carbon sink of European forests between 1950 and 2000. Glob Change Biol 17:3274-92.

Birdsey R, Pregitzer K, Lucier A. 2006. Forest carbon management in the United States: 1600-2100. J Environ Qual 35:1461-9.

Bugmann H. 2001. A review of forest gap models. Clim Change 51:259-305.

Cavin L, Mountford EP, Peterken GF, Jump JS. 2013. Extreme drought alters competitive dominance within and between tree species in a mixed forest stand. Funct Ecol 27:1424-35.

Ciais P, Schelhaas MJ, Zaehle S, Piao SL, Cescatti A et al. 2008. Carbon accumulation in European forests. Nat Geosci 1:4259.

Erb KH, Kastner T, Luyssaert S, Houghton RA, Kuemmerle T et al. 2013. Bias in the attribution of forest carbon sinks. Nat Clim Change 3:854-6.

FAO (2010) Global forest resources assessment 2010: main report. Forestry Paper 163.

Farquhar GD, von Caemmerer S, Berry JA. 1980. A biochemical model of photosynthetic $\mathrm{CO}_{2}$ assimilation in leaves of $\mathrm{C} 3$ species. Planta 149:78-90.

Hale K (2015) Long-term carbon storage in a semi-natural British woodland. PhD thesis, University of Liverpool.

Haxeltine A, Prentice IC. 1996. BIOME3: an equilibrium terrestrial biosphere model based on ecophysiological constraints, resource availability, and competition among plant functional types. Glob Biogeochem Cycles 10:693-709.

Hickler T, Smith B, Sykes MT, Davis MB, Sugita S, Walker K. 2004. Using a generalized vegetation model to simulate vegetation dynamics in northeastern USA. Ecology 85:519-30. 
Hickler T, Vohland K, Feehan J, Miller PA, Smith B et al. 2012. Projecting the future distribution of European potential natural vegetation zones with a generalized, tree species-based dynamic vegetation model. Glob Ecol Biogeogr 21:50-63.

IPCC. 2013. Climate change 2013: the physical science basis. Contribution of Working Group I to the fifth assessment report of the intergovernmental panel on climate change. In: Stocker TF, Qin D, Plattner G-K, Tignor M, Allen SK, Boschung J, Nauels A, Xia Y, Bex V, Midgley PM, Eds. Cambridge, United Kingdom and New York, NY: Cambridge University Press. p. 1535. doi:10.1017/CBO9781107415324

Keith H, Mackey BG, Lindenmayer DB. 2009. Re-evaluation of forest biomass carbon stocks and lessons from the world's most carbon-dense forests. Proc Natl Acad Sci USA 106:11635-40.

Keith H, Mackey B, Berry S, Lindenmayer D, Gibbons P. 2010. Estimating carbon carrying capacity in natural forest ecosystems across heterogeneous landscapes: addressing sources of error. Glob Change Biol 16:2971-89.

Lehsten V, Sykes MT, Scott AV, Tzanopoulos J, Kallimanis A, Mazaris A, Verburg PH, Schulp CJE, Potts SG, Vogiatzakis I. 2015. Disentangling the effects of land-use change, climate and $\mathrm{CO}_{2}$ on projected future European habitat types. Glob Ecol Biogeogr 24:653-63.

Mackey B, Prentice IC, Steffen W, House JI, Lindenmayer D et al. 2013. Untangling the confusion around land carbon science and climate change mitigation policy. Nat Clim Change 3:552-7.

Meinshausen M, Smith S et al. 2011. The RCP GHG concentrations and their extension from 1765 to 2300 . Clim Change 109:213-41. doi:10.1007/s10584-011-0156-z.

Mountford EP, Peterken GE. 2003. Long-term change and implications for the management of wood pastures: experience over 40 years from Denny Wood, New Forest. Forestry 76:19-43.

Murray MB, Cannell MGR, Smith RI. 1989. Date of budburst of fifteen tree species in Britain following climatic warming. $\mathrm{J}$ Appl Ecol 26:693-700.

Nabuurs GJ, Lindner M, Verkerk PJ, Gunia K, Deda P et al. 2013. First signs of carbon sink saturation in European forest biomass. Nat Clim Change 3:792-6.

Pan Y, Birdsey RA, Fang J, Houghton R, Kauppi PE et al. 2011. A large and persistent carbon sink in the world's forests. Science 333:988-93.

Peterken GF, Jones EW. 1987. Forty years of change in Lady Park Wood: the old growth stands. J Ecol 75:477-512.

Peterken GF, Jones EW. 1989. Forty years of change in Lady Park Wood: the young-growth stands. J Ecol 77:401-29.

Prentice IC, Cramer W, Harrison SP, Leemans R, Monserud RA, Solomon AM. 1992. A global biome model based on plant physiology and dominance, soil properties and climate. J Biogeogr 19:117-34.
Prentice IC, Sykes MT, Cramer W. 1993. A simulation model for the transient effects of climate change on forest landscapes. Ecol Model 65:51-70.

Rautiainen A, Wernick I, Waggoner PE, Ausubel JH, Kauppi PE. 2011. A national and international analysis of changing forest density. PLoS One 6:e19577.

Schuck A, Van Brusselen J, Päivinen R, Häme T, Kennedy P, Folving S. 2002. Compilation of a calibrated European forest map derived from NOAA-AVHRR data. Internal Report 13. Annex 3. Joensuu: European Forest Institute.

Shugart HH. 1984. A theory of forest dynamics. The ecological implications of forest succession models. New York: Springer.

Shugart HH. 1998. Terrestrial ecosystems in changing environments. Cambridge: Cambridge University Press.

Sitch S, Smith B, Prentice IC, Arneth A, Bondeau A et al. 2003. Evaluation of ecosystem dynamics, plant geography and terrestrial carbon cycling in the LPJ dynamic global vegetation model. Glob Change Biol 9:161-85.

Smith B, Prentice IC, Sykes MT. 2001. Representation of vegetation dynamics in the modelling of terrestrial ecosystems: comparing two contrasting approaches within European climate space. Glob Ecol Biogeogr 10:621-37.

Sykes MT, Prentice IC, Cramer W. 1996. A bioclimatic model for the potential distributions of north European tree species under present and future climates. J Biogeogr 23:203-33.

Thomas SC, Martin AR (2012) Dryad wood carbon content database. doi:10.5061/dryad.69sg2. Accessed 11 December 2013.

UK Meterological Office. Met Office Integrated Data Archive System (MIDAS) Land and Marine Surface Stations Data (1853-current), [Internet]. NCAS British Atmospheric Data Centre. January 2014. http://badc.nerc.ac.uk/view/badc.nerc. ac.uk_ATOM_dataent_ukmo-midas.

Vanguelova EI, Nisbet TR, Moffat AJ, Broadmeadow S, Sanders TGM, Morison JIL. 2013. A new evaluation of carbon stocks in British forest soils. Soil Use Manag 29:169-81.

Weedon GP, Gomes S, Viterbo P, Shuttleworth WJ, Blyth E, Österle H, Adam JC, Bellouin N, Boucher O, Best M. 2011. Creation of the WATCH forcing data and its use to assess global and regional reference crop evaporation over land during the twentieth century. J Hydrometeorol 12:823-48. doi:10.1175/2011JHM1369.1.

Wirth C, Messier C, Bergeron Y, Frank D, Fankhänel A. 2009 Old-growth forest definitions: a pragmatic view. Ecol Stud 207:11-33.

Wramneby A, Smith B, Samuelsson P. 2010. Hotspots of vegetation-climate feedbacks under future greenhouse forcing in Europe. J Geophys Res Atmos 115:D21119.

Zaehle S, Bondeau A, Carter TR, Cramer W, Erhard M et al. 2007. Projected changes in terrestrial carbon storage in Europe under climate and land-use change, 1990-2100. Ecosystems $10: 380-401$ 